\title{
THE IMPORTANCE OF ICEBREAKERS AND WARM-UP ACTIVITIES IN LANGUAGE TEACHING
}

\author{
Ayhan Diril \\ Gaziosmanpasa University, Department of Foreign Languages, \\ Karşıyaka street. 2nd street. Number 35, 60100 Tokat, Turkey \\ e-mail: ayhandiril@yahoo.com
}

\begin{abstract}
Warm-up activities play a great role in language teaching. They are the springboards for the new materials to be presented. Before going for a run, we do not force ourselves to jump out of the front door and sprint straight up the hill. Instead, we walk briskly for a few minutes before we break into a jog. Likewise, we should not start off English classes by plunging directly into a lesson. We should prefer a gentler approach of easing students into what might be their first English thoughts of the day. So, we start every class with a warm-up activity. Otherwise, we cannot get the clear image when the right frequency is not found.
\end{abstract}

\section{Introduction}

As teachers when we see the students' readiness in their eyes, we feel more confident and ready to present our subjects. In a class we cannot expect everybody to be eager to receive whatever is presented to them.

When we go for a run, we do not jump out of the front door and sprint straight up the hill. Instead, we walk briskly for a few minutes before we break into a jog. Likewise, we should not start off English classes by plunging directly into a lesson. We should prefer a gentler approach of easing students into what might be their first English thoughts of the day. So, we start every class with a warm-up activity. Students who speak their native languages most of the day often find themselves tongue-tied when they arrive in the English class. That is why we can conclude that moving between languages requires a mental regulation.

\section{$1 \quad$ What Is an Icebreaker?}

Let us have a look at the term ice-breaker. The term "icebreaker" comes from the phrase "break the ice", which refers to special ships called "icebreakers" that are designed to break up ice in the Arctic regions. And just as these ships make it easier for other ships to travel, an icebreaker helps to clear the way for learning to take place by making the learners more comfortable by helping to bring about conversation. As the name suggests, an ice breaker session is designed to "break the ice" at an event or meeting. The technique is often used when people who do not usually work together, or may not know each other at all, meet for a specific, common purpose.

\section{$2 \quad$ What Is a Warm-up Exercise?}

In sports the term warm-up is used very often. It is the act of preparing for an athletic event or workout by exercising or practicing for a short time beforehand. Warming up helps reduce your risk of injury and pains that come with the exercise.

In teaching a language we also need warm-up activities, as jumping right into an English lesson is difficult for some learners. They should be concentrated on the subject. As soon as 
the teacher enters the class, s/he should do her/his best to draw the students' attention to adjust them into the learning mood. English teachers can help their students accomplish this goal by beginning their classes with simple warm-ups. These engaging activities allow students to ease into English and prepare to delve into complex topics of study.

\section{$3 \quad$ What Should Warm-ups Be Like and What Is Their Significance?}

Warm-up activities are essential teaching techniques for good teachers and trainers. Warmups should always be success-oriented, as this is the feeling we want students to have at the beginning and end of a class. This feeling will make them more comfortable in trying new structures and taking risks. A productive warm-up should always be related to our language objectives and involve relevant language. Warm-ups should never be done for the sake of just doing nothing or filling time. In an English-as-a-Second-Language class, warm-ups are a great way to start classes as they get students in an English-learning frame of mind.

A warm-up should be a part of your everyday lesson plan and, of course, after greeting it is the first thing you do with your ESL students. It should be an easy exercise that all students can participate in. This participation is important because it creates a fun focus on English in the classroom and gets the students ready to listen to their teacher. It is also the moment when you start sailing as the ice is broken. An effective warm-up serves as a springboard into the subject or target language of the lesson.

We should be careful about the time spent on warm-ups. If they take too long, then valuable time gets lost from the main focus of the lesson and students have less time to acquire the new subject. They should last about 5-10 minutes, so that they can fulfil their goal of preparing students for the transition of entering or leaving the class.

During this stage of the lesson, we should not correct the students. Assistance will be fine, especially if some people have difficulty participating in the activity. Correction not only interferes in the flow of the activity, but also forms a teacher-centered lesson.

Warm-ups set the tone of the lesson and get students to begin thinking and focusing on English. It may have been a few days, a week, or even longer since they last used English. A little time spent by doing a warm-up activity will improve receptivity later.

They also provide a transition into the topic. An activity at the start of the lesson activates the pre-existing knowledge on a subject, and it may even get students to use some of the ideas, vocabulary, or even grammar important to the lesson.

Warm-ups provide the teacher with important opportunities to evaluate character and ability. After all, some students work well together, and others do not. Some students have good days and others bad ones. During the initial activity, the teacher can determine who will form the best groups for the following activities.

We can summarize the importance of using warm-ups in teaching a language like this:

- They have pedagogical importance in teaching a foreign language.

- They lessen the students' worries and help them to learn better.

- They decrease the monotony of the lesson and increase motivation and interest.

- They encourage creative and spontaneous use of the language.

- They help to have student focus on learning.

- They bring freedom of movement. 
- They help students to express their feelings.

- They help students to be in harmony with others.

- They contribute to development of vocabulary.

- They introduce games which help to form permanent knowledge.

The students are naturally motivated and have the atmosphere to discover life and solve the problems they face easily.

\section{$4 \quad$ Practical Examples}

After talking about the importance of warm up activities I would like to describe a few of them for you.

\subsection{Dirty Board Game}

Material: Whiteboard markers.

This activity can be done before or after a regular lesson. Students close their books and notebooks. The teacher asks them to remember and tell back what key words stayed in their minds about the lesson. For example, if the lesson is about a story, they come to the board randomly and write the related words on any space of the board. A few minutes later the white board will be totally full of words, which will make it hard to find an individual word quickly. Then you may point at the words and ask them to tell the information about that word. So this is the revision part. As a final stage we can form 2 groups and ask them to come to the board 2 by 2 .

They stand in front of the board facing their friends. You tell any word you choose and ask them to find it first. Whoever finds and touches the word as the first, gets the point.

From my own experience, I can say that this activity is one of the best ones for a revision of the previous lesson. Students do their best to remember what has been studied. While running to the board they wake up and start to participate in the lesson more actively. The childish feeling hidden in every individual comes to life again.

\subsection{Shopping Bag}

Students are put in groups of 8-10 people.

The first student in the group starts by saying the following sentence:

"Yesterday I went to the market and bought some oranges."

The next person in the group repeats the first sentence and adds another thing that they bought. E. g.: "Yesterday I went to the market and I bought some oranges and bananas."

Each person in turn repeats the sentence and adds another item. The students have to concentrate hard to remember all the things in the correct order. If they cannot remember the chain sentence, they will be out of the game.

\subsection{DJ Game}

A student is called to the board as a radio DJ. The headphone is put on his/her head. On the table, there is a CD player with some songs. The student pretends to be a DJ by talking to any student he chooses in the class and chats for a while. He can ask him about his location, likes, dislikes. Then he asks to whom he would like to send the next song. Then the DJ plays a song for a while. This goes on for 5 or 10 minutes. So the music relaxes them. 


\subsection{Secretary Game}

This activity can be done to form a competition atmosphere in class. The teacher sticks a sheet of paper on the board. The paper includes a set of short sentences; at least as many as the number of the pupils in the class. The sentences can be about the previous lesson or preparation for the next one. Two or three groups are formed. Each student at the end of his group is chosen as a secretary. When the activity starts, one student from each group runs to the board and reads the sentence. Then s/he runs to the secretary and dictates it. If s/he forgets the whole sentence, s/he may come back and look at it again. When s/he is done with the sentence, s/e asks the next student in the group to do the same. The group which has more sentences with the correct spelling wins -the game.

This activity creates a competitive atmosphere in the class. Even the most passive student does something for the group to be the winner. If the teacher rewards the winning group of course, it is more effective.

\section{Conclusion}

The climate of the world is changing. In our childhood, there used to be a smooth transition between the seasons. We should know that after spring there should be summer. Warm-ups are said to have the same role.

Ayhan Diril, B. C. 


\section{DŮLEŽITOST PROLOMENÍ LEDU A ZAHŘÍVACÍCH AKTIVIT VE VÝUCE CIZÍCH JAZYKŮ}

Zahř́vací aktivity hrají významnou roli ve výuce cizích jazyků. Jsou odrazovým můstkem pro výklad nového učiva. Než se dáme do běhu, nenutíme se skočit ze dveří a běžet prř́mo do kopce. Místo toho jdeme pomaleji několik minut, než se rozběhneme. Obdobně bychom se neměli okamžitě ponořit do hloubky lekce. Místo toho bychom měli dávat přednost pozvolnějšímu př́stupu, např. tím, že motivujeme žáky a studenty zabývat se svými prvními myšlenkami $\mathrm{v}$ angličtině ten den. Takovou príípravnou aktivitou začínáme každou vyučovací hodinu, abychom studenty náležitě získali pro učivo.

\section{DIE WICHTIGKEIT VON EISBRECHERN UND AUFWÄRMAKTIVITÄTEN IM FREMDSPRACHENUNTERRICHT}

Aufwärmaktivitäten spielen eine wichtige Rolle im Fremdsprachenunterricht. Sie bilden ein Sprungbrett für neuen Unterrichtsstoff. Bevor wir zu rennen beginnen, zwingen wir uns nicht aus der Tür zu springen und gleich bergauf zu rennen. Stattdessen setzen wir uns erst langsam in Bewegung, bevor wir zu rennen beginnen. In analoger Weise sollten wir uns nicht gleich in die Tiefe des Sprachunterrichts stürzen, sondern einer allmählichen Annäherung den Vorzug geben, indem wir die Schüler und Studenten dazu anregen, sich mit ihren ersten englischen Gedanken des Tages zu beschäftigen. Mit einer solchen Aufwärmaktivität beginnen wir jede Unterrichtsstunde, um die Studenten auf den Lehrstoff einzustimmen.

\section{ZNACZENIE PRZEŁAMANIA LODÓW I CZYNNOŚCI ROZGRZEWAJĄCYCH W NAUCZANIU JĘZYKÓW OBCYCH}

Działania rozgrzewające odgrywają ważną rolę w nauczaniu języków obcych. Są punktem wyjścia dla przekazania nowego materiału. Zanim rozpoczniemy bieg, nie zmuszamy się, aby wybiec przez drzwi i ruszyć prosto pod górkę. Zamiast tego ruszamy najpierw powoli, przygotowujemy się do późniejszego większego tempa. Tak samo nie powinniśmy od razu zanurzyć się $\mathrm{w}$ głębokich wodach lekcji. Zamiast tego powinniśmy na początku przyjąć wolniejsze podejście, przykładowo motywując uczniów, aby w danym dniu spróbowali po raz pierwszy zacząć myśleć po angielsku. Taką czynnością przygotowawczą rozpoczynamy każdą lekcję, aby uczniów odpowiednio przygotować i zmotywować do przyjęcia zaplanowanego do omówienia nowego materiału. 